\title{
Effect of Rhizobium and Micronutrients on Yield and Yield Attributing Characters of Garden pea (Pisum sativum L.)
}

\author{
Koyal Mohanty $^{1 *}$, Debi Archana Nayak ${ }^{1}$, Premananda Mahapatra ${ }^{1}$ \\ and Nitish Kumar Jena ${ }^{2}$ \\ ${ }^{1}$ Department of Horticulture, Institute of Agricultural Sciences, Siksha 'O' Anusandhan \\ (Deemed To Be University) Bhubaneswar-751029, Odisha, India \\ ${ }^{2}$ ICAR-Indian Institute of Water Management, Chandrasekharpur, Bhubaneswar-751023, \\ Odisha, India \\ *Corresponding author
}

\begin{tabular}{l} 
Key w or d s \\
Garden pea, N:P:K, \\
Rhizobium, \\
Micronutrients, \\
Yield \\
\hline Article Info \\
\hline $\begin{array}{l}\text { Accepted: } \\
\text { 20 January } 2021 \\
\text { Available Online: } \\
\text { 10 February } 2021\end{array}$ \\
\hline
\end{tabular}

\section{A B S T R A C T}

The present investigation entitled "Effect of Rhizobium and Micronutrients on yield and yield attributing characters of Garden pea (Pisum sativum L.)" was carried out during rabi Season, 2019-2020 at Research Farm, Chhatabara, Bhubaneswar. The Recommended Dose of Fertilizer (RDF) used for garden pea was 55:70:50 kg NPK/ha along with FYM @ 30t ha ${ }^{-1}$.The chemical fertilizers were applied in three levels i.e. $50 \%, 75 \%$ and $100 \%$ of the RDF with various combinations of rhizobium culture and micronutrients. The experiment was carried out to study the effect of rhizobium and micronutrients at different levels of fertilizer on yield attributing characters of garden pea. Application of different levels of $\mathrm{N}, \mathrm{P}, \mathrm{K}$ in combination with rhizobium and micronutrients increase the different yield attributing characters, like maximum number of pods per plant (44.66), number of seeds per pod $(7.1)$, pod length $(9.21 \mathrm{~cm})$, pod girth $(4.16 \mathrm{~cm})$, individual pod weight $(6.12 \mathrm{~g})$ and pod yield $\left(65.66 \mathrm{q}^{\mathrm{h}} \mathrm{ha}^{-1}\right)$ was observed in the treatment. Thus, it may be suggested that recommended dose of fertilizer $\left(55: 70: 50 \mathrm{~kg} \mathrm{NPK} / \mathrm{ha}^{-1}\right.$ ) with rhizobium (@ 400g $/ 2 \mathrm{~kg}$. of seed) and micronutrients $(0.2 \%)$ application gave maximum yield in case of garden pea where all yield attributing characters mentioned above has topped the list.

\section{Introduction}

There is a great challenge before India is to enhance the production of nutritious food in a sustainable manner, besides feeding the country's large population, also increases the income of the farmers by giving them the economic security. It is highly essential to commercialize vegetable production which can play major role in meeting the shortage of food, particularly when many more mouths are required to feed from the limited land 
resources. Adaptation of advanced production technology which has created unprecedented pressure on the limited natural resources base which in turn may disturb the ecology, thereby affecting the entire social scenario.

Number of vegetables contributes a lot in human dietary schedule with respect to different nutrients, minerals and vitamins, visà-vis providing carbohydrate, protein, fibre etc. At present, India has credibility of producing 314 MT of vegetables (2018-19), position $2^{\text {nd }}$ among vegetable producing countries of the world. The per capita availability of vegetable in India is also low i.e, 160g. against 285g. as per recommendation of Food and Agriculture Organisation (FAO).

Further the prediction indicates that there is a need of 127.2 MT of vegetables other than potato and tubers to meet the estimated population of $1200 \mathrm{M}$. people by (2020-21), (The Hindu, survey of Indian Agriculture, 2009). Garden pea is a crop which can only be grown in rabi season in the state. Most of the farmers prefer to grow field pea because of its higher yield, but garden pea cultivation is limited in Odisha. Garden pea being fertilizers responsive has an yield potential $12.15 \mathrm{t} / \mathrm{ha}$ (Kalloo et al., 2005).

Moreover it is less susceptible to storage pest as compared to other pulses. Apart from this garden pea is quite nutritious and is a potential source of Protein (5.42\%), Mineral (2.5\%), Vitamins $(46 \%)$ besides some medicinal values. it act as an anti ageing factor which helps to prevent obesity, lower the cholesterol content of the blood and therefore recommended for curing heart and kidney related diseases. The present investigation was carried out to observe the response of different levels of RDF with rhizobium and micronutrients on yield and yield attributing characters of garden pea.

\section{Materials and Methods}

The present investigation entitled "Effect of Rhizobium and Micronutrients on yield and yield attributing characters of Garden pea (Pisum sativum L.)" was carried out during rabi Season, 2019-2020 at Research Farm, Chhatabara, Bhubaneswar. The experiment was carried out to study the effect of rhizobium culture and micronutrients at different levels of fertilizers on yield and yield attributing characters of garden pea. Arkel variety was selected for this experiment. 10 treatments using different recommended dose of fertilizer (NPK: 55:70:50) $\mathrm{kg} / \mathrm{ha}^{-1}$, rhizobium culture $(400 \mathrm{~g} / 2 \mathrm{~kg}$ of seed) and micronutrients $(0.2 \%)$ were applied in different treatments (Table 1).

The sowing was done in rabi season using Randomized Block Design (RBD). The spacing was $30 \mathrm{~cm} \times 15 \mathrm{~cm}$ in $3 \mathrm{~m} \mathrm{X} 3 \mathrm{~m}$ plot size with total area of $388.44 \mathrm{~m}^{2}$ for each treatment. From each plot 10observation plants were selected in each treatment to calculate the pod length, pod girth, number of pods per plant, number of seeds per pod, individual pod weight and pod yield per hectare. The details of the treatments which were applied in the experiment is given below.

\section{Results and Discussion}

The maximum number of pods per plant was observed with $\mathrm{T}_{10}$ (44.66) presented in table 2 Fig. 1 which was significantly superior to all other treatments followed by $\mathrm{T}_{9}(40.33)$ and $\mathrm{T}_{7}$ (36.37) respectively. The lowest number of pods per plant was recorded with $\mathrm{T}_{2}(20.00)$ which were statistically inferior to other treatments. Application of $100 \%$ NPK along with micronutrients and rhizobium significantly influenced the production of maximum number of pods per plant than other treatments tried in the experiment. The increase in pod number may be due to the 
apportioning efficiency that is increased production of photosynthesis towards the economic parts as pods and also the required hormonal balance in the plant system. Similar findings were also reported by Taura and Fatima (2008) in Cowpea, Teotia et al., (1983) in Garden pea, Sharma and Kalia (1998) in Field pea.

The maximum number of seeds per pod was recorded with $\mathrm{T}_{10}$ (7.1) as significant differences were exhibited in number of seeds per pod presented in (Table 2 and Fig. 2). This is significantly superior than other treatments followed by $T_{9}$ (6.65) and $T_{7}$ (6.13). The lowest seed per pod was observed with $\mathrm{T}_{2}$ (4.28) which was statistically inferior among rest of the treatments. Application of $100 \%$ NPK along with rhizobium and micronutrients significantly increase the production and maximum number of seeds per pod than other treatment tried. This might be due to application of micronutrients (Multiplex: Copper, Magnesium, Boron, Molybdenum, Zinc and Manganese) along with balanced fertilization and rhizobium helped in translocation of photosynthesis resulting in better pod formation as well as seeds. Improvement in pod yield there by seed yield in garden pea is due to application of sulphur and boron could be attributed to fulfillment of crop demand by higher assimilation and translocation of photosynthesis from leaves to seeds or the economic parts as pods. The micronutrients also maintain the required hormonal balance in the plant system. The micronutrients help to enhance the tissue differentiation from somatic to reproductive, meristematic activity and development of floral primordia might have increased resulting in more flowers and a greater number of seeds per pod. Similar findings were also reported by Shivran et al., (2000) in Peagon pea, Nasreen and Farid (2003) in Garden pea, Parry et al., (2016) in Garden pea and Kumar et al., (2012) in Garden pea.
Significant differences were exhibited in length of the pods $(\mathrm{cm})$ among different treatments (Table 2 and Fig. 3). The maximum length of the pods was measured with $\mathrm{T}_{10}$ $(9.21 \mathrm{~cm})$ which was significantly superior than rest of the treatments followed by $\mathrm{T}_{9}$ $(8.94 \mathrm{~cm})$ and $T_{7}(8.53 \mathrm{~cm})$ respectively. The lowest and inferior pod length $(\mathrm{cm})$ was observed with $\mathrm{T}_{2}(6.25 \mathrm{~cm})$ which was statistically analyzed.

From (Table 2 and Fig. 4), it is clearly revealed that the pod girth varies significantly in different treatments. Maximum pod girth was recorded in $\mathrm{T}_{10}(4.16 \mathrm{~cm})$ followed by $\mathrm{T}_{9}$ $(4.13 \mathrm{~cm})$ and $T_{7}(4.11 \mathrm{~cm})$ respectively. It is significantly superior than other treatments. The lowest value was recorded with $T_{2}$ $(3.15 \mathrm{~cm})$ which is statistically inferior than rest of the treatments.

The present investigation revealed that both the length and girth of the pods were formed to be significant with respect to combined effect of $100 \%$ NPK with rhizobium and micronutrients over other treatments. However, the highest dose of NPK with rhizobium and micronutrients increased the length and girth over the pod over the treatments which were in confirmation with the findings of Ramana et al., (2010) in French bean.

From the data tabulated and presented in (Table 2 and Fig. 5), revealed that the maximum individual pod weight was recorded in $\mathrm{T}_{10}(6.12 \mathrm{~g})$ which is significantly superior to the other treatments followed by $\mathrm{T}_{9}(5.20 \mathrm{~g})$ and $\mathrm{T}_{7}(4.98 \mathrm{~g})$ respectively. However, the lowest individual pod weight was observed with $\mathrm{T}_{2}(3.13 \mathrm{~g})$ which is statistically inferior to rest of the treatments. The weight of the pod was found to be significant with respect to the combined effect of $100 \%$ NPK along with rhizobium and micronutrients over other treatments. 
Table.1 The experiment comprised of the following treatments

\begin{tabular}{|c|c|}
\hline Notations & Treatments \\
\hline $\mathbf{T}_{\mathbf{1}}$ & RDF(55:70:50 kg/ha) \\
\hline $\mathbf{T}_{\mathbf{2}}$ & $50 \% \mathrm{NPK}+$ Rhizobium \\
\hline $\mathbf{T}_{\mathbf{3}}$ & $75 \% \mathrm{NPK}+$ Rhizobium \\
\hline $\mathbf{T}_{\mathbf{4}}$ & $100 \% \mathrm{NPK}+$ Rhizobium \\
\hline $\mathbf{T}_{\mathbf{5}}$ & $50 \% \mathrm{NPK}+$ Micronutrients \\
\hline $\mathbf{T}_{\mathbf{6}}$ & $75 \% \mathrm{NPK}+$ Micronutrients \\
\hline $\mathbf{T}_{\mathbf{7}}$ & $100 \% \mathrm{NPK}+$ Micronutrients \\
\hline $\mathbf{T}_{\mathbf{8}}$ & $50 \% \mathrm{NPK}+$ Rhizobium + Micronutrients \\
\hline $\mathbf{T}_{\mathbf{9}}$ & $75 \% \mathrm{NPK}+$ Rhizobium + Micronutrients \\
\hline $\mathbf{T}_{\mathbf{1 0}}$ & $100 \% \mathrm{NPK}+$ Rhizobium + Micronutrients \\
\hline
\end{tabular}

Table.2 Effect of fertilizer levels, rhizobium and micronutrients on yield and yield attributing characters of garden pea var. Arkel

\begin{tabular}{|c|c|c|c|c|c|c|}
\hline Treatments & $\begin{array}{c}\text { No. of } \\
\text { pods/plant }\end{array}$ & $\begin{array}{c}\text { No. of } \\
\text { seeds/pod }\end{array}$ & $\begin{array}{l}\text { Pod } \\
\text { length } \\
(\mathrm{cm})\end{array}$ & $\begin{array}{l}\text { Pod } \\
\text { girth } \\
(\mathbf{c m})\end{array}$ & $\begin{array}{l}\text { Individual } \\
\text { pod weight } \\
\text { (g) }\end{array}$ & $\begin{array}{l}\text { Yield } \\
\text { (q/ha) }\end{array}$ \\
\hline $\begin{array}{c}\text { T}_{1}-\operatorname{RDF}(55: 70: 50) \\
\text { kg/ha. }\end{array}$ & 32.35 & 5.73 & 8.00 & 4.05 & 4.32 & 47.66 \\
\hline $\begin{array}{c}\text { T }_{2}-50 \% \text { NPK+ } \\
\text { Rhizobium }\end{array}$ & 20.00 & 4.28 & 6.25 & 3.15 & 3.13 & 31.33 \\
\hline $\begin{array}{c}\text { T }_{3}-75 \% \text { NPK+ } \\
\text { Rhizobium }\end{array}$ & 26.11 & 4.87 & 6.88 & 3.33 & 3.43 & 44.33 \\
\hline $\begin{array}{l}T_{4}-100 \% \text { NPK+ } \\
\text { Rhizobium }\end{array}$ & 35.34 & 5.98 & 8.27 & 4.08 & 4.54 & 49.22 \\
\hline $\begin{array}{l}\mathbf{T}_{\mathbf{5}} \mathbf{- 5 0 \%} \text { NPK + } \\
\text { Micronutrients }\end{array}$ & 30.33 & 4.54 & 7.2 & 3.54 & 3.78 & 41.99 \\
\hline $\begin{array}{l}\text { T }_{6}-75 \% \text { NPK + } \\
\text { Micronutrients }\end{array}$ & 26.32 & 5.00 & 7.48 & 3.76 & 4.10 & 40.33 \\
\hline $\begin{array}{l}\text { T }_{7-100 \%} \text { NPK + } \\
\text { Micronutrients }\end{array}$ & 36.37 & 6.13 & 8.53 & 4.11 & 4.98 & 53.22 \\
\hline $\begin{array}{c}\mathrm{T}_{\mathbf{8}} \mathbf{- 5 0 \%} \text { NPK+ } \\
\text { Micronutrients + } \\
\text { Rhizobium }\end{array}$ & 25.30 & 5.22 & 7.91 & 3.98 & 3.96 & 45.66 \\
\hline $\begin{array}{c}\mathrm{T}_{9}-\mathbf{7 5 \%} \mathrm{NPK}+ \\
\text { Micronutrients + } \\
\text { Rhizobium }\end{array}$ & 40.33 & 6.65 & 8.94 & 4.13 & 5.20 & 55.22 \\
\hline $\begin{array}{l}\mathrm{T}_{10}-100 \% \mathrm{NPK}+ \\
\text { Micronutrients + } \\
\text { Rhizobium }\end{array}$ & 44.66 & 7.1 & 9.21 & 4.16 & 6.12 & 65.66 \\
\hline SE(M) \pm & 0.097 & 0.015 & 0.023 & 0.014 & 0.087 & 0.186 \\
\hline CD at $5 \%$ & 0.288 & 0.045 & 0.069 & 0.043 & 0.259 & 0.554 \\
\hline
\end{tabular}


Fig.1 Effect of fertilizer levels, rhizobium and micronutrients on no. of pods/plant in garden pea.

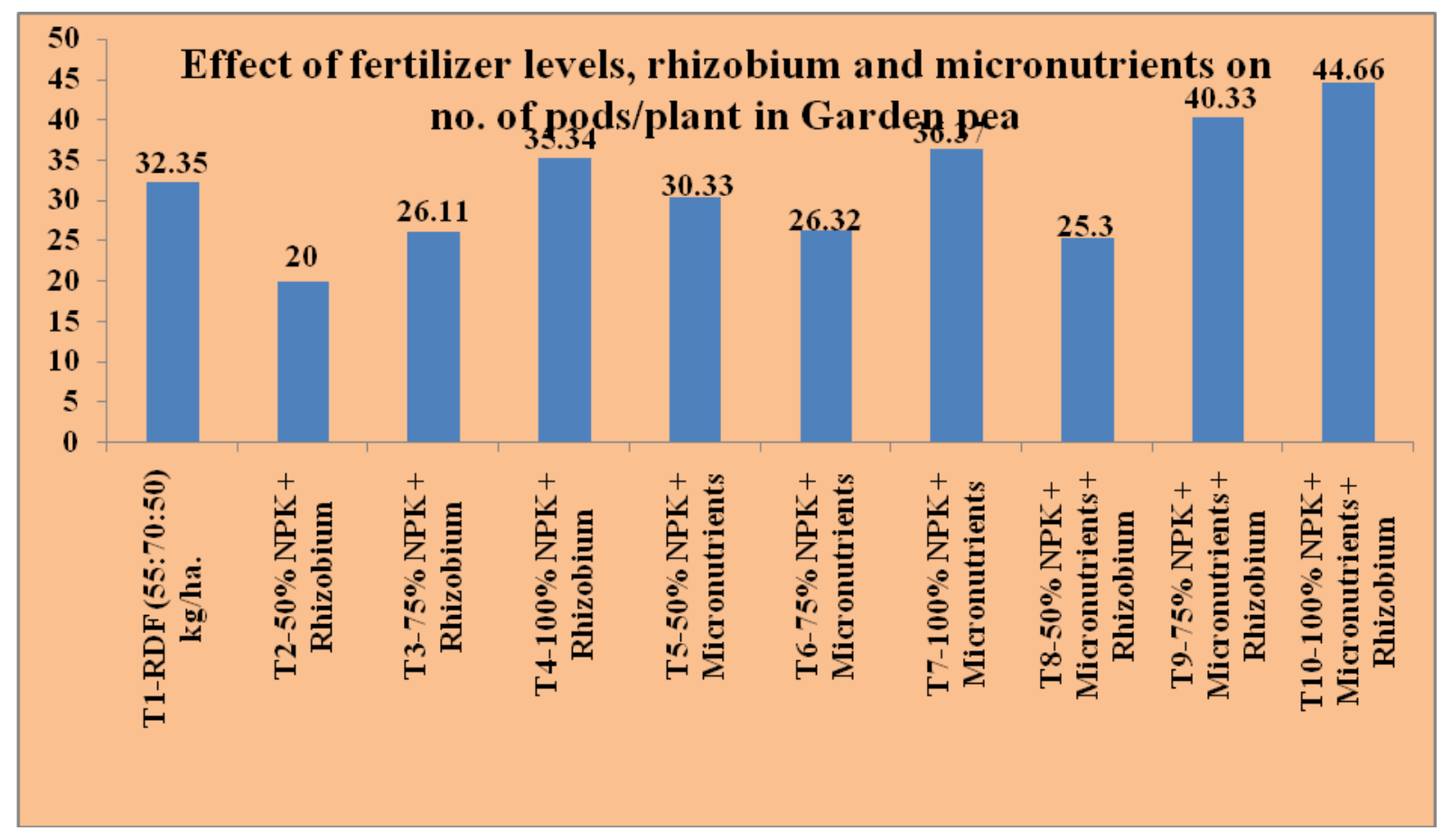

Fig.2 Effect of fertilizer levels, rhizobium and micronutrients on no. of seeds/pods in garden pea.

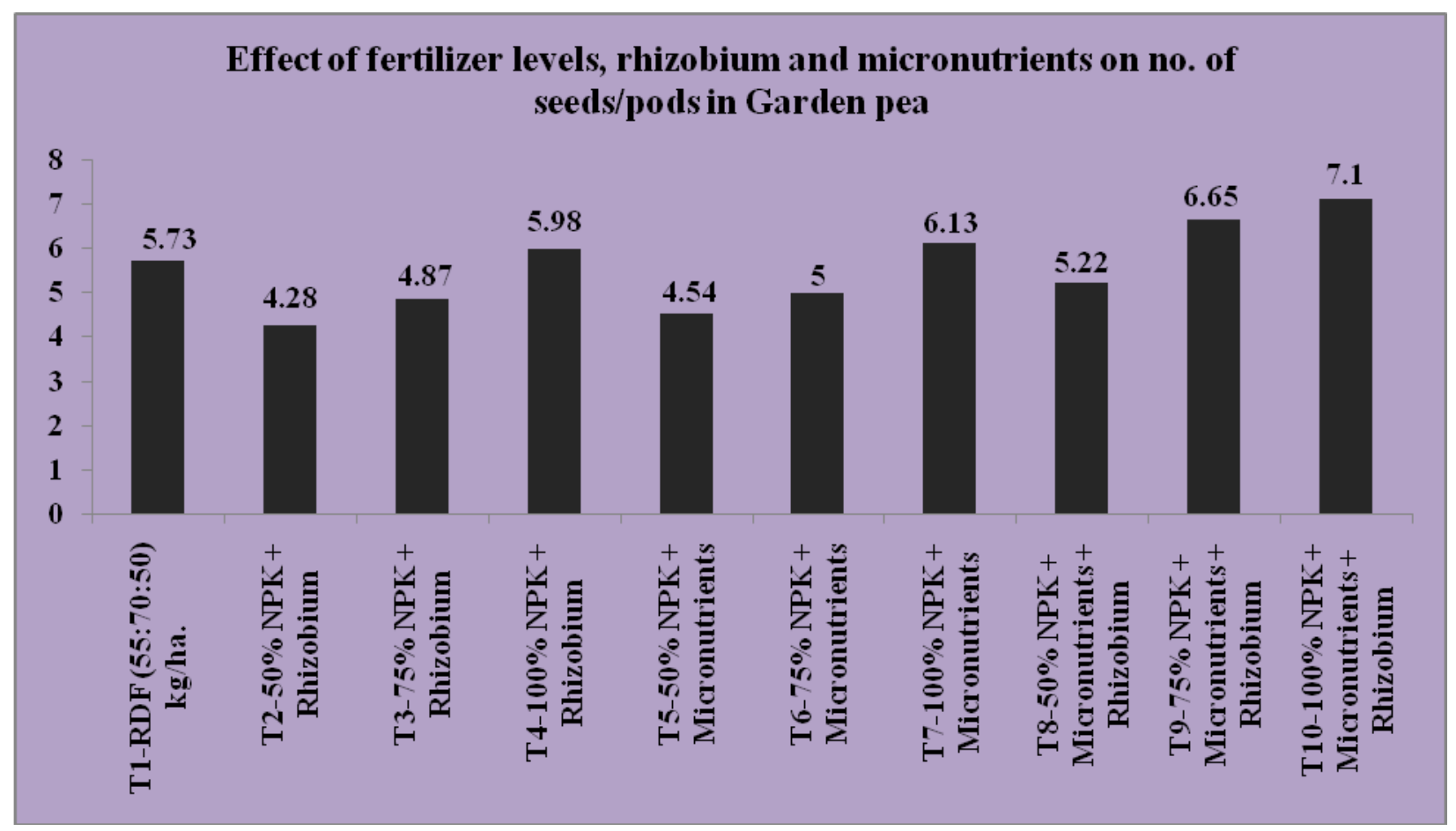


Fig.3 Effect of fertilizer levels, rhizobium and micronutrients on pod length in garden pea.

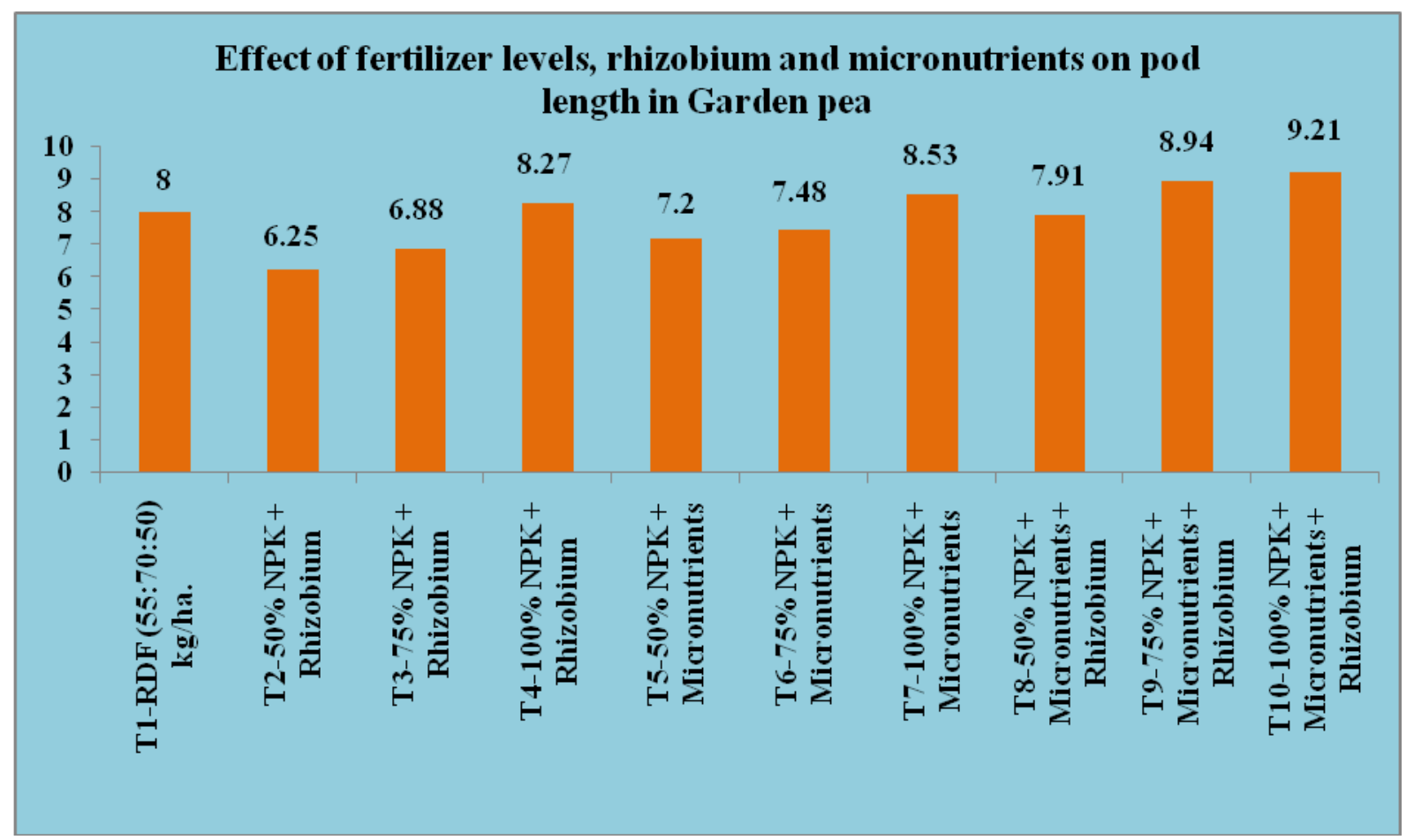

Fig.4 Effect of fertilizer levels, rhizobium and micronutrients on pod girth in garden pea.

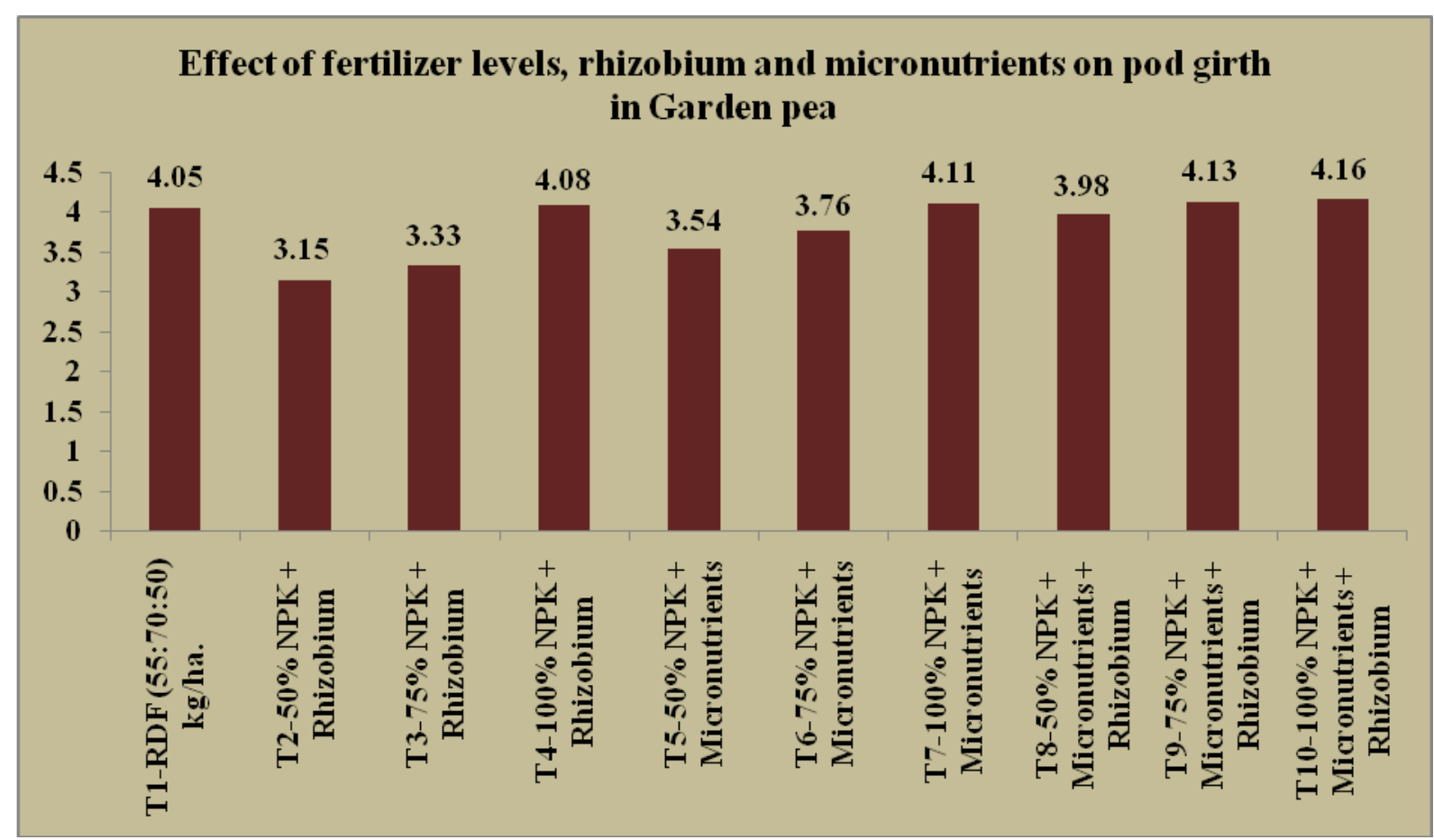


Fig.5 Effect of fertilizer levels, rhizobium and micronutrients on individual pod weight in garden pea

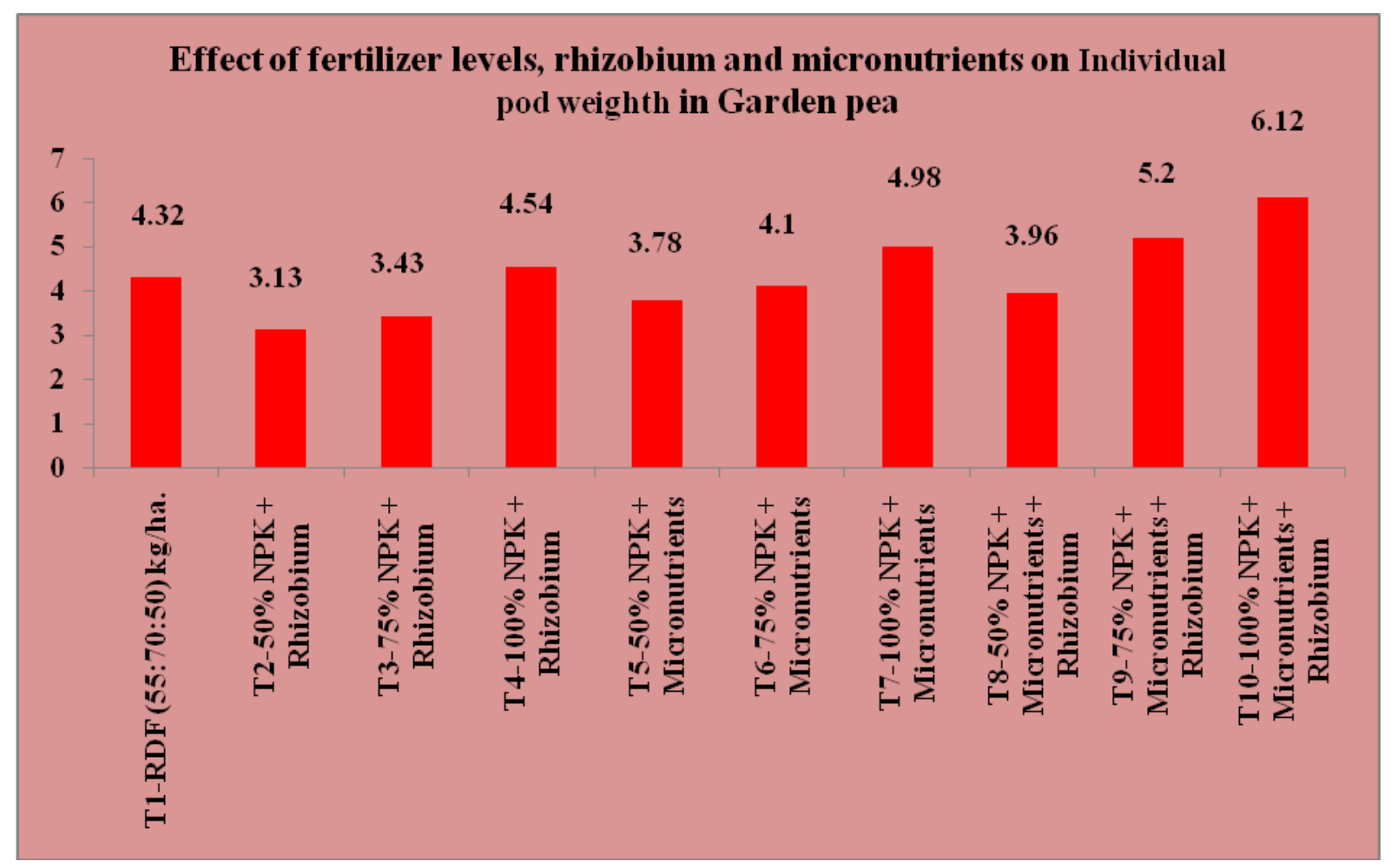

Fig.6 Effect of fertilizer levels, rhizobium and micronutrients on yield (q/ha) in garden pea.

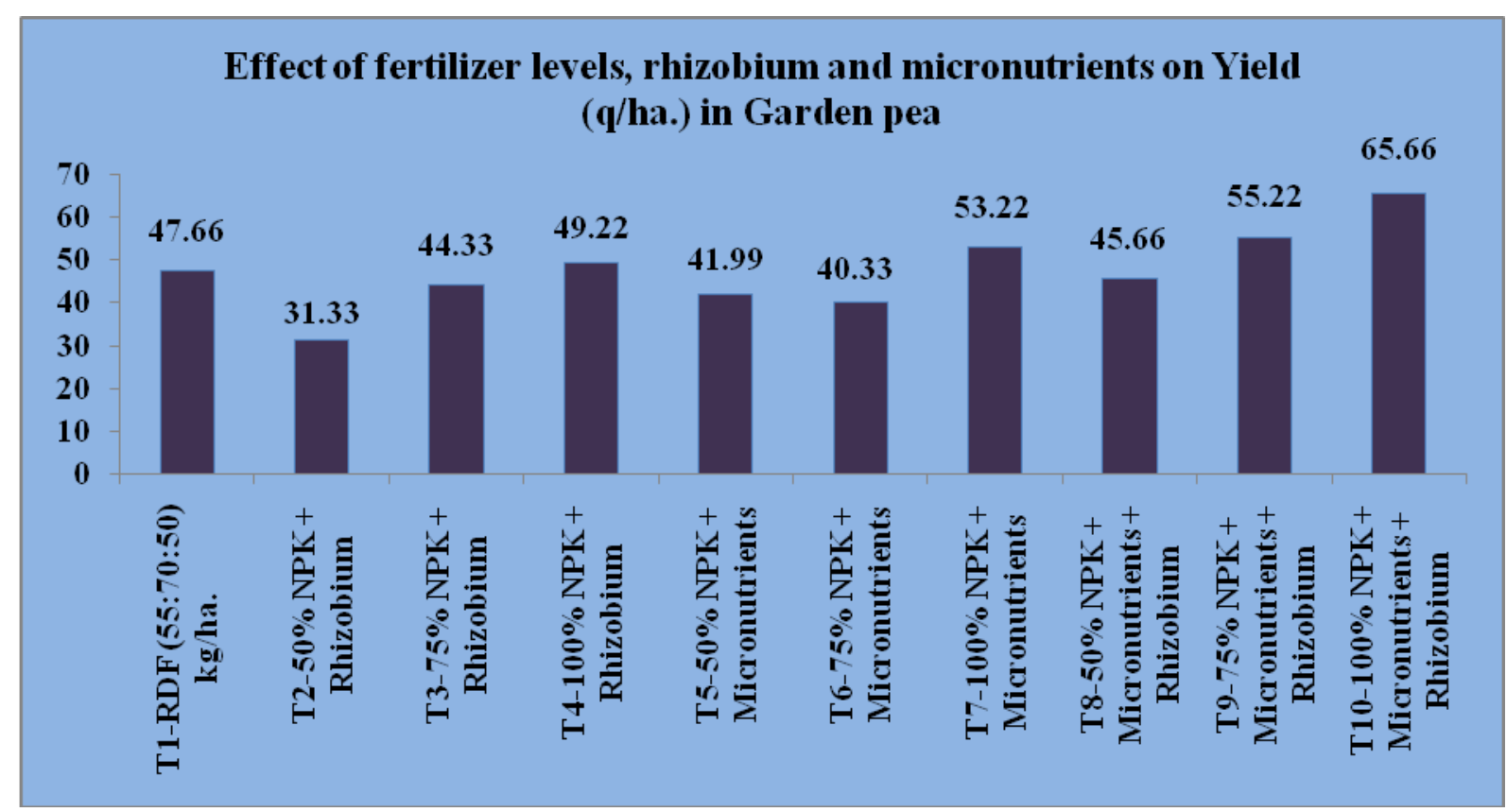


Large size pod with increased weight were recorded by applying $100 \%$ NPK with rhizobium and micronutrients which might have favoured the production of more amount of food material and accumulation of the same in the pod there by increasing the individual pod weight. The result is tally with the findings of Asmaa R. Mohammed et al., (2010) in Snap bean and Gharib et al., (2009) in Snap bean.

Significant differences were exhibited among different treatments with respect to yield (q/ha) which can be seen in (Table 2 and Fig. 6 ). The maximum yield was recorded with $\mathrm{T}_{10}$ $\left(65.66 \mathrm{q} / \mathrm{ha}^{-1}\right)$ that is significantly superior followed by $\mathrm{T}_{9}\left(55.22 \mathrm{q} / \mathrm{ha}^{-1}\right)$ and $\mathrm{T} 7(53.22$ $\left.\mathrm{q} / \mathrm{ha}^{-1}\right)$ and $\mathrm{T}_{4}\left(49.22 \mathrm{q} / \mathrm{ha}^{-1}\right)$ respectively.

However, the lowest yield was observed in $\mathrm{T}_{2}$ $\left(31.33 \mathrm{q} / \mathrm{ha}^{-1}\right)$ which is statistically inferior than rest of the treatments. Application of different levels of NPK in combination with rhizobium and micronutrients increase the yield of fresh pods per plant in an increasing order with that of increase in the dose of NPK combined with rhizobium and micronutrients. Maximum yield $\left(65.66 \mathrm{q} / \mathrm{ha}^{-1}\right)$ was recorded with the application of $100 \%$ RDF (chemical fertilizer) with rhizobium and micronutrients which was significantly higher than other treatments.

The increase in the yield could be due to the greater availability of nutrients in the soil and better nodulation under the influence of inoculation resulting in better growth and development which might be attributed to better mobilization of phosphorus and increased allocation of photosynthesis towards the economic parts and also the hormonal balance on the plant system. The finding corroborates with the findings of Rajput et al., (2004) in Garden pea, Ramana et al., (2010) in French bean, Osman et al., (2010) in Faba bean.
The salient findings of the present study, entitled "Effect of Rhizobium and Micronutrients on yield and yield attributing characters of Garden pea (Pisum sativum L.)", clearly reveals that significant variation having maximum pod length of $(9.21 \mathrm{~cm})$ was recorded in the treatment receiving $100 \%$ RDF (55:70:50 NPK kg ha ${ }^{-1}$ ) in combination with rhizobium treatment and micronutrients spray. Significantly maximum number of pods per plant (44.66), number of seeds per pod (7.1), individual pod weight $(6.12 \mathrm{~g})$ and yield $\left(65.66 \mathrm{q} / \mathrm{ha}^{-1}\right)$ was also observed in the above treatments which were statistically superior to rest of the treatments. Increase in the yield attributing characters in above treatments might be due to the combined effect of rhizobium $(400 \mathrm{~g} / 2 \mathrm{~kg}$ seed $)$ and micronutrients (Multiplex)@0.2\% with different levels of $\mathrm{N}: \mathrm{P}: \mathrm{K} \mathrm{kg} \mathrm{ha}{ }^{-1}$ which in turn expressed better yield and yield attributing characters of garden pea.

\section{References}

Fatma Gharib AE. 2014. Improving Growth and Productivity of Faba bean Plants by Foliar Application of Thiourea and Aspartic Acid, International Journal of Plant \& Soil Science, 3(6): 724-736

Kumar A, Singh ON and Kumar R. 2012. Effect of Integrated Nutrient Management on growth, seed yield and economics of pea (PisumsativumL.) and fertility changes, Journal of Food Legume, 25(7): 121-124

Nasreen S and Farid ATM. 2003. Influence of different nutrients on growth and yield of Garden pea (Pisum sativum L.), Indian Journal of Agronomy, 48: 206209

Osman, Awad, Gagal, Elaziz, Fatima, IzzeldinAbd and Hassan, Gaadalla A. 2010. Effect of biological and mineral fertilization on yield, chemical composition and physical 
characteristics of Faba bean (Vicia faba L.). Cultivar Seleim, Journal of Nutrition, 9(7): 703-708

Parry FA, Chattoo MA, Magray M, Ganie SA, Dar ZM and Masood A. 2016. Effect of different levels of sulphur and boron on growth and nodulation of Garden pea (Pisum sativum L.), Legume Research, 39(3): 466-469

Rajput RL and Pandey RN. 2004. Effect of method of application of bio-fertilizers on yield of pea (Pisum sativum L.), Legume Research, 22(4): 241-244

Ramana V, Ramakrishna M, Purushotam K and Balakrishna, Reddy K. 2010. Effect of bio-fertilizer on growth, yield attributes and yield of French bean (Phaseolus vulgaris L.), Legume Research, 33(3): 178-183

Sharma A and Kalia P. 1998. Correlation and path analysis of bi-parental progenies in Garden pea (Pisum sativum L.), Vegetable Science, 25: 26-31

Shivran PL, Ahlawat IPS and Shivran DR. 2000. Effect of phosphorus and sulphur on Pigeon pea (Cajanus cajan L.) and succeeding Wheat (Triticum aestivum L.) in Pigeon peawheat cropping system, Indian Journal of Agronomy, 45(1): 25-30

Taura DW and Fatima MS. 2008. Effect of organic and inorganic fertilizers on the vegetative and reproductive parts of some selected varieties of Cowpea (Vigna unguiculata L.), Department of Biological Science, 55(6): 178-185

Teotia, AS, Kalloo G, Dhankar and B.S. 1983. Correlation and path analysis in Garden pea. Journal of Horticultural Science, 12: 76-81

\section{How to cite this article:}

Koyal Mohanty, Debi Archana Nayak, Premananda Mahapatra and Nitish Kumar Jena. 2021. Effect of Rhizobium and Micronutrients on Yield and Yield Attributing Characters of Garden pea (Pisum sativum L.). Int.J.Curr.Microbiol.App.Sci. 10(02): 2776-2784.

doi: https://doi.org/10.20546/ijcmas.2021.1002.307 